\title{
A shelduck coracoid (Aves: Anseriformes: Tadorna) from the arid early Pleistocene of the Qinghai-Tibetan Plateau, China
}

\author{
Thomas A. Stidham, Xiaoming Wang, Qiang Li, and Xijun Ni
}

\begin{abstract}
An avian coracoid from the early Pleistocene Qigequan Formation in the Qaidam Basin, Qinghai Province, China, in the northern part of the Qinghai-Tibetan Plateau represents one of the few avian fossils from the region. The specimen is from an individual of a shelduck (Tadorna sp.), and its phylogenetic position is supported by the presence of a procoracoid notch (where the procoracoid foramen is greatly reduced) and other osteological characters. The previous hypothesis of extreme aridity in the Qaidam Basin during the early Pleistocene is lessened by the presence of a shelduck (along with the fossil record of proboscideans) that is part of a clade that occurs and breeds on the arid Qinghai-Tibetan Plateau today. In addition, the occurrence of Chinese shelducks in arid environments today likely evolved in combination with the increase in elevation and intensifying aridity in the plateau region since the early Pleistocene.
\end{abstract}

Thomas A. Stidham. Key Laboratory of Vertebrate Evolution and Human Origins, Institute of Vertebrate Paleontology and Paleoanthropology, Chinese Academy of Sciences, Beijing 100044, China presbyornis@gmail.com

Xiaoming Wang. Department of Vertebrate Paleontology, Natural History Museum of Los Angeles County, 900 Exposition Blvd., Los Angeles, California 90007, USA xwang@nhm.org

Qiang Li. Key Laboratory of Vertebrate Evolution and Human Origins, Institute of Vertebrate Paleontology and Paleoanthropology, Chinese Academy of Sciences, Beijing 100044, China liqiang@ivpp.ac.cn Xijun Ni. Key Laboratory of Vertebrate Evolution and Human Origins, Institute of Vertebrate Paleontology and Paleoanthropology, Chinese Academy of Sciences, Beijing 100044, China nixijun@ivpp.ac.cn

Keywords: Qinghai; Aves; Tadorna; shelduck; Pleistocene; Qaidam Basin

\section{INTRODUCTION}

The Tibetan region has long been an area of study because of its high elevation and related cold climate. The uplift of the Qinghai-Tibetan Plateau, in combination with the glacial-interglacial climatic shifts of the Pleistocene, is thought to have driven speciation and the origin of many Tibetan endemic species (e.g., Lei et al., 2014). The biota on the Qinghai-Tibetan Plateau today includes endemic birds and artiodactyls, and has been hypothesized as the center of origin for some cold climate adapted mammals (e.g., Deng et al., 2011) and some avian taxa (Lei et al., 2014) that have spread 


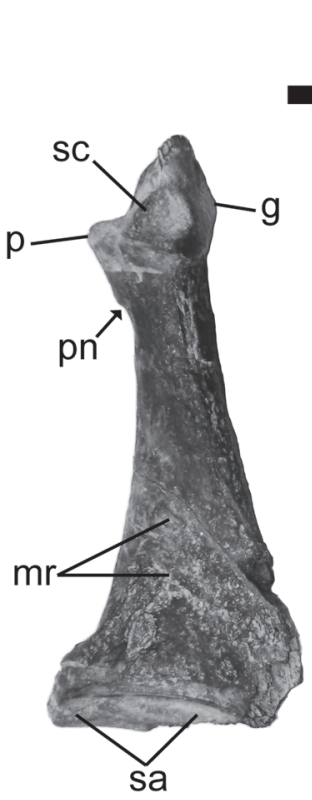

1
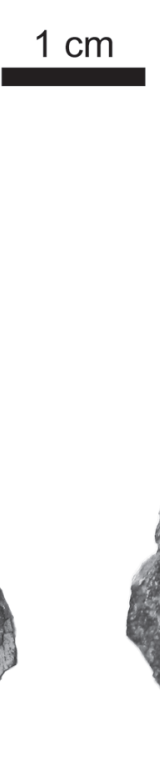

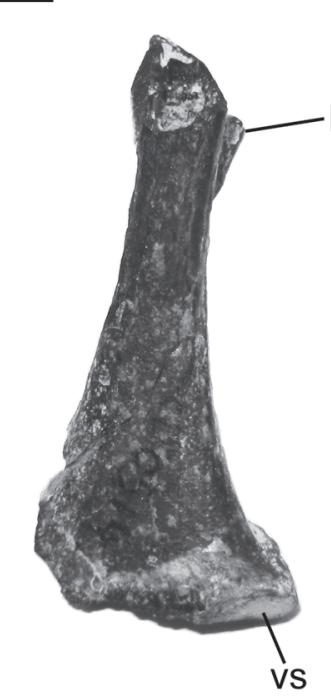

2

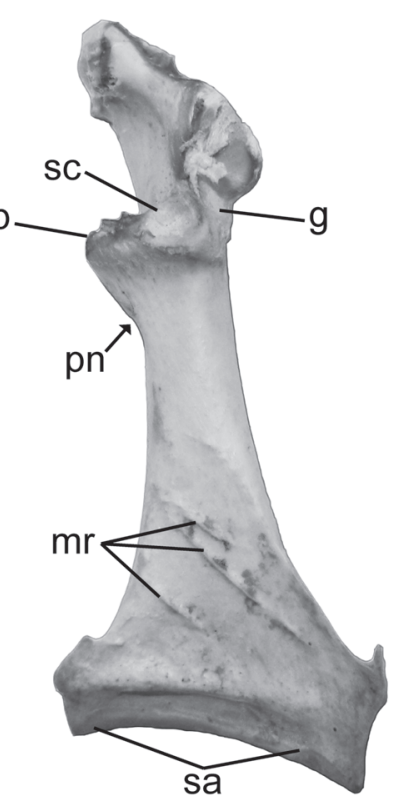

3

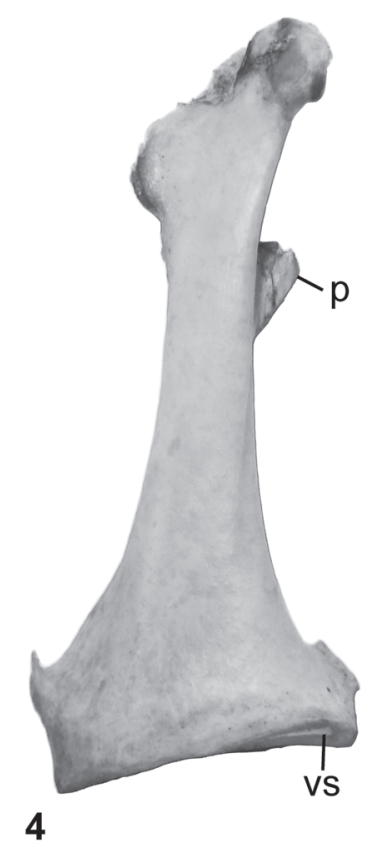

FIGURE 1. Comparison of the fossil Tadorna sp. (IVPP V20114) in 1 and 2, and the coracoid of Tadorna ferruginea (IVPP OV1745) in $\mathbf{3}$ and $\mathbf{4}$. $\mathbf{1}$ and $\mathbf{3}$ are in dorsal view, and $\mathbf{2}$ and $\mathbf{4}$ are in ventral view. Abbreviations: g-glenoid; mrmuscular ridges; p-procoracoid process; pn-procoracoid notch; sa-sternal articulation; sc-scapular cotyle; and vs-ventral sternal articulation.

to lower elevation environments during past periods of climate change. However, hypotheses of the timing of clade divergences, as well as any taxon's past presence in those montane regions (i.e., Pleistocene refugia), largely are not derived from the sparse fossil (avian and mammalian) record in the region. Occupation of such high elevations and arid environments has led to the evolution of morphological and molecular adaptations among the organisms there. For example, late Cenozoic aridification on the Qinghai-Tibetan Plateau has been hypothesized to have led to the evolution of thickboned cyprinid fish (Chang et al., 2008). Within birds, several species of waterfowl, including the South American tadornine Chloephaga melanoptera, that live at such high elevations are known to have evolved convergent modifications to their hemoglobin as an adaptation to the lowered oxygen levels present at those altitudes (e.g., McCracken et al., 2009, 2010). Furthermore, the Ground Tit (Pseudopodoces humilis) that lives across the Tibetan Plateau exhibits evolutionary changes to its cardiac function that are thought to be modifications for high altitude life (Cai et al., 2013). Documentation of fossil vertebrates at high elevation is relatively rare, limiting the detailed study of vertebrate evolution (including tempo) and adaptations to those environments.

In general, the fossil record of vertebrates is poorly known from the Qinghai-Tibetan Plateau (Wang et al., 2013, 2014), and the known avian fossils from the region are restricted to a lost trackway from the Oligocene or early Miocene (Xing et al., 2013), late Miocene eggshell fragments initially referred to as Struthio, and a coracoid initially identified as Anas sp. (misspelled as "Ana sp." in Wang et al., 2007, p. 374; Figure 1). The eggshell fragments previously published as Struthio are not from Struthio camelus, but possibly are referrable to the paleognath ootaxon Struthiolithus. That eggshell is currently under study along with other Neogene eggshell from across China. A reexamination of the waterfowl specimen (see below) demonstrates that while it is an anatid, it is not a member of Anas. Instead, it appears to belong to another anatid clade; allied to the species in Tadorna. That specimen comes from the Qaidam Basin in the northern Qinghai-Tibetan Plateau, China (Figures 2, 3), and it was deposited during a period of increasing aridity and is among the few fossil bird specimens known from the Tibetan Plateau. 


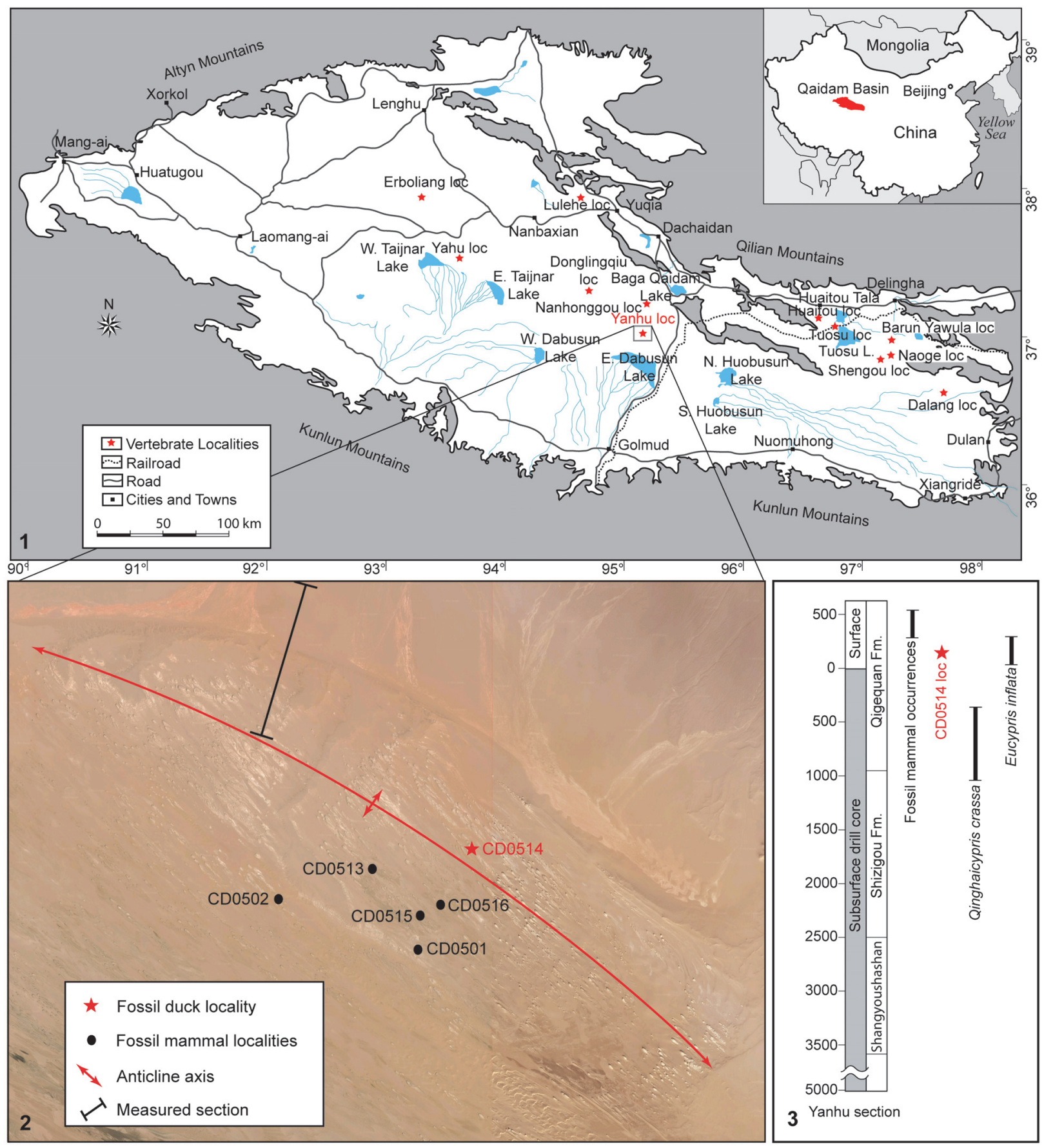

FIGURE 2. 1 map of Qaidam Basin showing major areas of vertebrate fossil-producing localities (modified from Wang et al., 2007, figure 1). 2 satellite image of the Yanhu Anticline showing the location of the fossil bird locality (CD0514) and other fossil mammal localities. 3 stratigraphic occurrences of vertebrate and ostracod fossils. Yanhu surface and drill sections, as well as ostracod occurrences, are based on unpublished data of Sun Zhencheng, archived in the China University of Petroleum.

Members of the Tadornini include extant and extinct species on all continents except Antarctica and are known as fossils back into the late Oligocene and early and middle Miocene (e.g., Olson, 1985; Alvarez and Olson, 1978; Worthy and
Pledge, 2007; Worthy et al., 2007; Worthy, 2009; Zelenkov, 2013). The extant genera of Tadornini include Tadorna, Cyanochen, Alopochen, Chloephaga, and Neochen (e.g., Livezey, 1997). Worthy and Lee (2007) discuss the oldest potential 


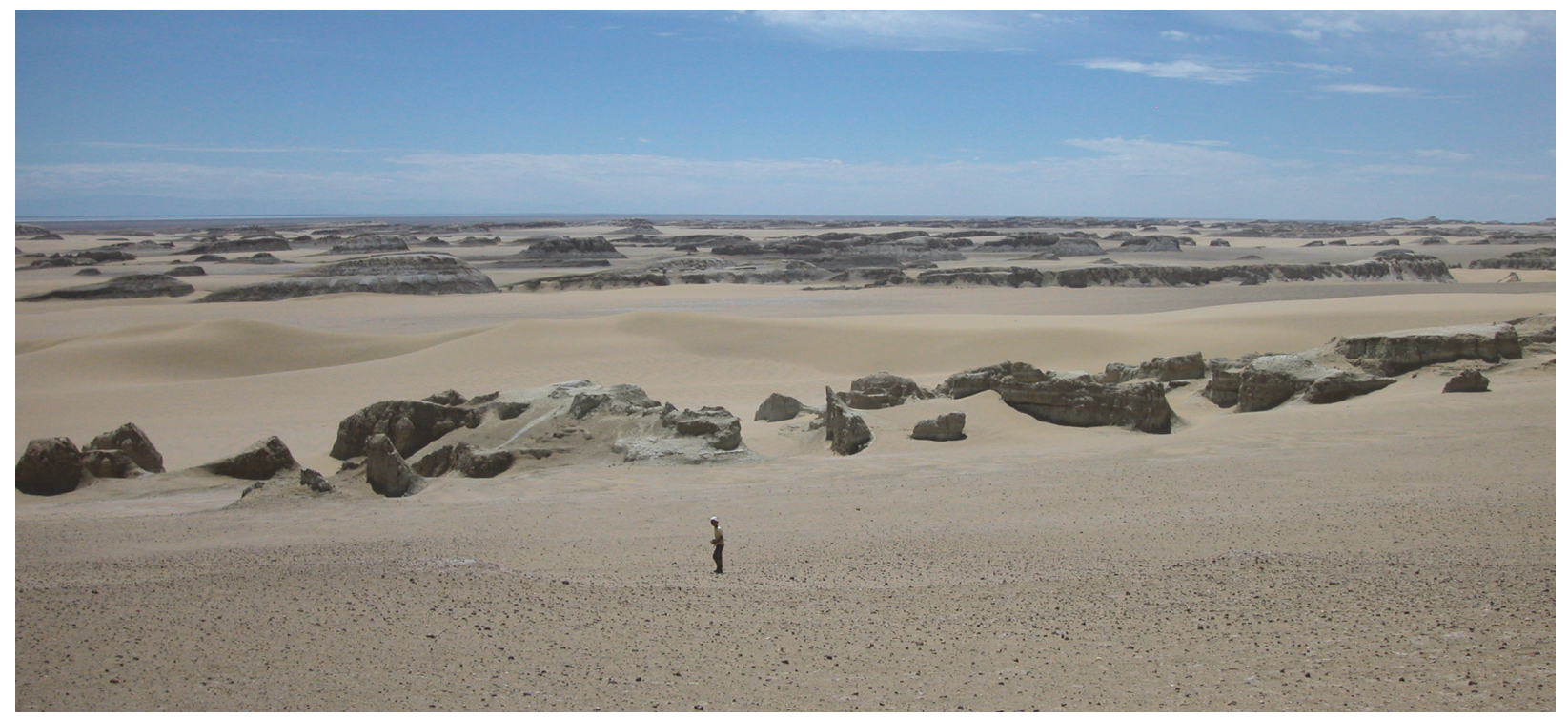

FIGURE 3. Photograph of the Yanhu Anticline exposures. The wind-eroded exposures are mostly oriented along the prevailing winter northwesterly winds, roughly coinciding with the axis of the anticline. Person in foreground for scale (photo by Xiaoming Wang).

records of the Tadornini, including Miotadorna in the early-middle Miocene of New Zealand (Worthy et al., 2007), and Worthy (2009) described Australotadorna from the late Oligocene of Australia. The shelducks (species in the genus Tadorna) are composed of seven species of extant birds that occur across the Old World (including the possibly extinct Crested Shelduck, Tadorna cristata, from eastern Asia) (Livezey, 1997). The phylogenetic relationships among the members of Tadornini vary depending on the taxonomic composition of the species sampled and the data used (osteological vs. molecular), but they indicate that the species of Tadorna are closely related to Alopochen and Chloephaga within Tadornini (Donne-Goussé et al., 2002; Worthy and Lee, 2008; Worthy, 2009; Fulton et al., 2012). The placement of Miotadorna within the crown clade of Tadornini constrains the origin of that clade to at least the early or middle Miocene (Worthy and Lee, 2008; Worthy, 2009), and that result is consistent with molecular clock estimates for the timing of Tadornini diversification (Fulton et al., 2012).

There are several Neogene records of specimens of Tadorna and other potential Tadornini/ Tadorna fossils in the Miocene and Pliocene of Asia. Kurochkin (1985) described tadornine bones from the late Pliocene of the Transbaikal area of Russia (Asia), Zelenkov and Martynovich (2013) reported tadornine bones from the early-middle
Miocene of Baikal, and Zelenkov and Kurochkin (2011) mention middle Miocene Tadorna specimens from Mongolia. In addition, there is a scapula that may belong to Tadornini from the middle Miocene of Thailand (Cheneval et al., 1991). Furthermore, Zelenkov (2013) discussed the evolution of the tadornine birds in Asia and potential role of aridification in their geographic and temporal distribution during the Neogene. He suggests that aridification might be the cause of the absence of Tadornini in the latest Miocene deposits in Eurasia (Zelenkov, 2013). With the known fossil record, it appears that the shelduck group was present across large parts of Asia in the Miocene and Pliocene. Thus, their past presence in Qinghai-Tibetan Plateau is not unexpected given Tadornini fossil records in adjacent areas and the occurrence of species of Tadorna on the plateau today (MacKinnon and Phillipps, 2000; Lang et al., 2007; Yang et al., 2009; Li et al., 2010). The age of this Qaidam fossil falls within the early Pleistocene, a time that overlaps with the hypothesized temporal origin of some of the Tibetan endemic mammalian and avian lineages (Lei et al., 2014), in addition to one hypothesized speciation event within the crown group of Tadorna (e.g., Tadorna tadornoides vs. T. ferruginea + T. cana; Fulton et al., 2012). The description below uses the osteological terminology of Baumel and Witmer (1993) with English equivalents of the Latin terms. 


\section{SYSTEMATIC PALEONTOLOGY}

\author{
AVES Linnaeus, 1758 \\ ANSERIFORMES Wagler, 1831 \\ ANATIDAE Leach, 1820 \\ TADORNINI Reichenbach, 1849-1850 \\ TADORNA sp. Boie, 1822
}

Material. IVPP V20114 (Institute of Vertebrate Paleontology and Paleoanthropology, Beijing, China) is a partial right coracoid collected by Xiaoming Wang on August 5, 2005 (Figure 1).

Locality and Horizon. The specimen is from IVPP locality CD0514 (N37¹3'32.8" E95¹1'08.3" elevation 2,791 $\pm 5.1 \mathrm{~m}$ ), near the axis of the Yanhu Anticline, central Qaidam Basin, Qinghai Province, China (Figures 2, 3). It is from the Qigequan Formation and is early Pleistocene in age based on biochronology of ostracods and subsurface records in petroleum geologic explorations (Figure 2.3). Specifically, occurrences of the ostracod species Qinghaicypris crassa and Eucypris inflata below and above CD0514, respectively, are characteristic of basal Quaternary strata in central and eastern Qaidam Basin and have been calibrated to span the Matuyama magnetochron (C2r.1r-C2r.2r), that ranges between 1.945 and $2.581 \mathrm{Ma}$ (Sun et al., 1995; Yang et al., 1997; Hilgen et al., 2012). Wang and coauthors (2007) state that only astragali of an "antelope-sized" artiodactyl were found nearby (at localities CD0501 and CD0502), but enamel fragments of a gomphothere proboscidean also were found in the Yanhu anticline region (CD0515 locality; see Figure 2). Those Pleistocene proboscidean fossils have not been mentioned previously in the literature. Unfortunately, mammalian records are too fragmentary to be of help in age determination.

Specimen Description. The preserved bone is dark brown to black in color, and much of the bone surface is worn with many small bone flakes missing. The coracoid is broken just cranial to the scapular cotyle on the dorsal surface, and the area ventral to the scapular cotyle is missing. The lateral sternal corner is broken, and much of the sternal articulation surface is missing. The craniocaudal length of the specimen is $41.5 \mathrm{~mm}$. The bone surface is not 'spongy', and therefore the morphology and the specimen's size likely represent that of an adult individual (e.g., Watanabe and Matsuoka, 2013).

The scapular cotyle is a deep cup located near the lateral edge of the bone (Figure 1). The tip of the procoracoid is broken away leaving a blunt triangular process. There is no procoracoid foramen. However, there is a slight notch at the caudal base of the procoracoid and no evidence of an ossified ligament in the area (Worthy and Lee, 2008, character 42; Figure 1). Only the caudal end of the glenoid is preserved and is localized to the lateral surface of the bone. Caudal to the scapular cotyle, there are several subparallel muscular ridges on the dorsal surface that are oriented roughly at 45 degrees to the long axis of the bone. The dorsal area just cranial to the sternal articulation is slightly concave and does not have any pneumatic foramina (Worthy and Lee, 2008, character 47 ). The ventral surface of the caudal end of the coracoid is relatively flat (Worthy and Lee, 2008, character 48). The medial sternal articulation on the ventral surface does not extend above the adjacent areas of bone (Worthy and Lee, 2008, character 49). The dorsal surface of the preserved portion of the sternal articulation extends to the broken caudolateral edge. The medial edge of the coracoid shaft exhibits a low ridge extending from caudal to the base of the procoracoid to the level of the muscular ridges. The cranial tip of the preserved bone in the supracoracoideus fossa is slightly concave suggesting that the area below the glenoid was excavated (Worthy and Lee, 2008, character 46).

Taxonomic Comparisons. The presence of the procoracoid foramen is a crown group bird plesiomorphy, and its absence is a derived state found among some crown anatids (and convergently in other avian crown clades) (e.g., Mayr and Clarke, 2003). The reduction/absence of the procoracoid foramen (to a notch) in this Qinghai specimen supports its position within Anatidae since that foramen is present in the outgroups to Anatidae (within Anseriformes), but some anatids including some individuals and species from Anser, Branta, and Cygnus have a procoracoid foramen or notch formed by ossified ligaments (appendix 1 of Worthy and Lee, 2008, character 42). The absence of a pneumatic foramen on the dorsal sternal end of the coracoid is a derived character among Presbyornis + Anatidae (Worthy and Lee, 2008, character 47) and reinforces the identification of the fossil as an anatoid anseriform. Worthy and Lee (2008) mention that species of Tadorna exhibit at least a slight notch at the base of the procoracoid (not associated with ossified ligaments), as in this fossil (Figure 1). That particular morphology (character state) appears to be present only among species and individuals of Tadorna (a putative synapomorphy of the group), and it is reportedly absent in their close relatives Alopochen and Chloephaga (appendix 1 and data matrix from Worthy and Lee, 2008). While 
the depth, and even presence, of that notch may vary across individuals of Tadorna, the clear presence of the character state in this Qinghai fossil and among specimens of Tadorna supports their taxonomic placement together to the exclusion of other taxa that never exhibit the trait. The absence of a concave area on the ventral surface cranial to the sternal articulation (appendix 1 and data matrix from Worthy and Lee, 2008, character 48) eliminates Dendrocygna, Stictonetta, Thalassornis, most species of Oxyura, Malacorhnychus, Plectropterus, Mionetta, Manuherikia, and Nettapus (Worthy and Lee, 2008) as potential taxonomic affiliations for this fossil given its flat ventral surface. The ventral articular facet with the sternum is not a distinct raised facet elevated above the adjacent coracoid (Worthy and Lee, 2008, character 49), but exhibits an articulation nearly identical to that in Tadorna ferruginea (IVPP OV1745). That absence means that the Qaidam fossil is inconsistent with the character states in Dendrocygna, Thalassornis, Biziura, Nettapus, Cereopsis, Branta, Anser, Cygnus, Alopochen, Chloephaga, and Miotadorna (appendix 1 and data matrix from Worthy and Lee, 2008). The concavity below the glenoid in the supracoracoideus fossa (Worthy and Lee, 2008, character 46) is a homoplastic character among anatids and varies even within some genera (e.g., Miotadorna and Tadorna; appendix 1 and data matrix from Worthy and Lee, 2008). Thus, its utility for aiding in identification of this fossil specimen is limited. However, its presence in this fossil specimen eliminates Tadorna radjah (appendix 1 and data matrix from Worthy and Lee, 2008) as a possible identification. The fossil also shares size and subtle morphological features that are difficult to define with Tadorna. Among those features, the morphology, position, and size of the ridge on the medial side of the coracoid shaft, the relative position and size of the muscular ridge area, the morphology and size of the dorsal surface of the sternal articulation, and the position of the scapular cotyle are all extremely similar to those present in Tadorna ferriginea (IVPP OV1745).

Given those combinations of traits and their phylogenetic distribution, many anatid genera, can be excluded from consideration. The presence of the procoracoid notch (not associated with ossified ligaments) in this Qaidam specimen, however, points to allocation of this fossil among the species of Tadorna. Worthy and Lee (2008, appendix 1) mention a potentially homologous procoracoid notch (formed by ossified ligaments) also being present sometimes in specimens of Cygnus (swans) and some geese. However, those taxa are larger bodied as adults than the individual who produced IVPP V20114, and those larger birds also have a different state for Worthy and Lee's (2008) character 49 (above) than what is present in this fossil. Additionally, the absence of the notched procoracoid character in most anatid taxa and the close outgroups to Tadorna (e.g., Alopochen) would seem to indicate that the notches are instead analogous, and that the notch in Tadorna (not formed by a ligament) could be a distinct synapomorphy (appendix 1 and data matrix from Worthy and Lee, 2008). That notch character has not been reported from species allocated to Anas, even though species in that grouping share many of the above phylogenetic character states with this fossil (appendix 1 and data matrix from Worthy and Lee, 2008); thus, the prior assignment to Anas is rejected.

Livezey (1997) did not include any coracoid characters in his analysis of shelduck phylogeny, and the more recent work by Worthy (e.g., Worthy, 2009) has not focused on interspecific relationships within genera. Analyses of Tadornini phylogeny have given different results depending on the data analysed and the taxonomic composition of the analyses (e.g., Worthy, 2009; Fulton et al., 2012). In some studies, the species of Tadorna form a clade, and in other studies Alopochen is placed within the Tadorna group (Worthy, 2009). Thus, the combination of the fragmentary nature of the Qaidam specimen and the current knowledge of the phylogenetic distribution of coracoid characters limits the resolution of this specimen's taxonomic allocation. The Qaidam fossil appears to be from a non-Alopochen, non-Chloephaga tadornine based on the data available (i.e., Tadorna), and IVPP V20114 is nearly identical to extant species of Tadorna (Figure 1). In particular, the specimen is nearly equal in size to that of Tadorna ferruginea (IVPP OV1745), a species present on the QinghaiTibet Plateau today with a body mass averaging $\sim 1.1$ to $1.3 \mathrm{~kg}$ (larger than most species of Anas; Dunning, 2008). While this coracoid may belong to an extant species, it also is possible that it derives from a currently unknown extinct species. The data present in the specimen do not support a species level identification, and we refrain from attempting to over-identify the specimen.

\section{DISCUSSION}

There are several lakes in the Qaidam Basin today (Figure 2), and the paleontological and geological record demonstrates that lakes (freshwater, 
brackish, and saline) were present in the basin extending back into the Miocene (Wang et al., 2007; Chang et al., 2008; Yang et al., 2013; Mischke et al., 2010; Madsen et al., 2014). Despite the presence of Neogene and Quaternary lacustrine deposits in the Qaidam Basin, its geological and paleontological record indicates a long-term trend towards aridification that may correlate with the uplift of the Qinghai-Tibetan Plateau (e.g., Chang et al., 2008), and the basin is currently quite arid (see Figures 2.2 and 3 for images of the Yanhu Anticline). That aridification is seen in pollen records (Wu et al., 2011), in the increase in gypsum deposits, and the absence of fish faunas in the Pleistocene Qigequan Formation (Chang et al., 2008), but fish fossils have been reported in younger sediments elsewhere in the Qaidam Basin (Mischke et al., 2010). Other changes are present in lacustrine and paleontological records in the basin (e.g., Yang et al., 2013, Wu et al., 2011, Cai et al., 2012), and overall they indicate a significant shift to drier climates near 2.5 or $2.6 \mathrm{Ma}$, with additional (stepwise) aridity through the Pleistocene. Cai and others (2012) state that the vegetation in the western part of the basin during the same time interval when the shelduck fossil was deposited was a period with decreasing tree diversity, increasing shrubs and herbs, was cooler than the time before $\sim 2.6 \mathrm{Ma}$, and is considered by them to be classified as steppe desert. The age of this shelduck fossil is within Stage 2 of the core studied by Yang and others (2013) that appears to be climatically arid, but wetter than during the younger Pleistocene time intervals. The basin also has been argued to have been drier than present before $1.8 \mathrm{Ma}$, but climatic changes after $\sim 1.8 \mathrm{Ma}$ appear to have been increasingly arid (Zhuang et al., 2014; Li et al., 2014).

Palynological data from the Yanhu (Yahu in their usage) Anticline suggest a shift to drier climates near $\sim 2.6 \mathrm{Ma}$ that is nearly coincident with a change in ostracod faunas to a slightly brackish species (i.e., Qinghaicypris crassa) (Wu et al., 2011). That shift detected near 2.6 Ma is consistent across the basin with other records supporting an increase in regional aridity (e.g., Cai et al., 2012). However, the Yanhu Anticline data (Wu et al., 2011) show botanical variability through the time interval when the shelduck fossil was deposited (their Stage III) with increases and decreases in various plant taxa, and a short lived burst of coniferous trees near 2.0 Ma that likely indicates past climatic variability through that time interval.
Two species of Tadorna (i.e., T. ferruginea and T. tadorna) occur in the Qinghai-Tibet Plateau region today (and other parts of China and the world), and the Ruddy Shelduck ( $T$. ferruginea) also can be locally common there (Cheng, 1987; MacKinnon and Phillips, 2000; Lang et al., 2007; Brazil, 2009; Li et al., 2010). Species of Tadorna occur in a wide variety of habitats across the Old World (MacKinnon and Phillips, 2000), but their occupation of high elevation arid habitats is restricted to Asia. Therefore, the past occurrence of shelducks during the early Pleistocene in the Qaidam Basin likely would indicate (and is consistent with) the past presence of aquatic habitats (open water or marsh/reedy habitat), although Chinese Ruddy Shelduck populations inhabit more terrestrial habitats during the winter outside of the plateau (Luo et al., 2013). The Common Shelduck ( $T$. tadorna) also is known to occupy brackish and saline bodies of water (e.g., MacKinnon and Phillips, 2000), and both Chinese shelduck species will associate with water bodies in arid areas, but they are not restricted to that habitat (Cheng, 1987; Brazil, 2009). However, that habitat inference is consistent with the occurrence of ostracods in the Qigequan Formation.

Furthermore, brackish or saline water conditions in arid landscapes are within the realized niches of the two extant Chinese species of shelduck and likely those tolerances were present in individuals of those species in the deep past, although those (arid) habitats have not been posited previously for the Miocene and Pliocene fossils of this clade. The age range of the Qinghai Tadorna fossil (1.945 - $2.581 \mathrm{Ma}$ : the magnetochron's length) includes many glacial and interglacial cycles (Pillans and Gilbert, 2012) across a background of increasing regional aridity, and we cannot constrain during which particular climate regime this individual was present in the Qaidam Basin. Additionally, we cannot assume that the current occupation of the Qinghai-Tibetan Plateau by shelducks in the spring and summer seasons (with their migration to lower elevations in winter; Luo et al., 2013) occurred during the early Pleistocene. This individual may have been a resident (i.e., nonmigratory) or perhaps even only spent the winter in the basin. However, the presence of this adult shelduck individual at a minimum indicates the very likely past presence of both dietary items (such as invertebrates and plants) and aquatic habitats used by shelducks in the Qaidam Basin at one point in the early Pleistocene. Furthermore, it is possible that shelducks have inhabited this 
region continuously from the early Pleistocene to the present, but they also might have been absent during the hypothesized hyper arid intervals after $1.8 \mathrm{Ma}$, only returning later when large, possibly freshwater lakes were present in the basin (e.g., Mischke et al., 2010, Madsen et al., 2014). While Li and others (2014) state that large mammals (such as elephants, rhinoceroses, and giraffes) are absent from Quaternary deposits in the basin (as an indicator of faunal change in response to the climatic/vegetational shifts), the presence of gomphothere tooth fragments in the Yanhu Anticline (see above and Figure 2), demonstrates that proboscideans actually occurred in the basin during those early Pleistocene arid climates (contra Li et al., 2014). In combination with this Tadorna specimen, it would appear that the (vertebrate) faunal response to increasing aridity may have been more gradual than currently appreciated or that the interpreted level of aridity may not have been as extreme at that time.

Obviously, the late Cenozoic diversity of birds in Qinghai-Tibetan Plateau must have been higher than the current fossil record suggests (i.e., a turkey-sized bird, a large paleognath, and an anatid), but the Qaidam vertebrate fossil record dominated by mammals and fish (e.g., Wang et al., 2007) will require more research effort in order to expose more avian fossils and to derive the evolutionary and biogeographic data only hinted at by published molecular analyses. However, this anatid fossil from the northern Qinghai-Tibetan Plateau suggests that some birds, along with many mammal groups, that currently inhabit the high elevations of the Qinghai-Tibet Plateau may have a long history in the region extending at least into the early part of the glacial-interglacial cycles and increasing aridity of the Pleistocene. Their dispersal, speciation, and local adaptation at those high altitudes may have proceeded on pace with the changes in climate and elevation that occurred across the plateau, and over a long period of geologic time rather than the result of more recent post-glacial dispersals. The occurrence (and perhaps even preference) of some shelduck species for arid habitats also may have evolved during the climatic change associated with the uplift of the Qinghai-Tibetan Plateau.

\section{ACKNOWLEDGMENTS}

This project was supported by the Strategic Priority Research Program of Chinese Academy of Sciences (CAS, XDB03020501, XDB03020104),
National Basic Research Program of China (973 Program, No. 2012CB21904), CAS/SAFEA International Partnership Program for Creative Research Teams, Chinese National Natural Science Foundation (41472002 to QL, 41430102), Chinese Academy of Science Outstanding Overseas Scholar Fund (KL205208), and National Science Foundation of the United States (EAR0446699, 0444073, 0958704, 1227212 to XW). TAS was further supported by a Chinese Academy of Sciences Visiting Senior International Professorship Grant (2011Y2ZA01).

We gratefully acknowledge the late professor Sun Zhencheng of China University of Petroleum for sharing stratigraphic data of Qaidam Basin and Li Jiangtao of Qinghai Petroleum Bureau for showing us the Yanhu locality and other logistic help. We thank others who participated in fieldwork, including J. O'Connor (IVPP), Z.J. Tseng (AMNH, formerly USC), and G. Takeuchi (George C. Page Museum). We thank N. Zelenkov for access to Russian references, and to him, T. Worthy, G. Avery, and anonymous reviewers for comments on earlier versions of the manuscript.

\section{REFERENCES}

Alvarez, R. and Olson, S.L. 1978. A new merganser from the Miocene of Virginia (Aves: Anatidae). Proceedings of the Biological Society of Washington, 91:522532.

Baumel, J.J. and Witmer, L. 1993. Osteologica, pp. 45132. In Baumel, J.J., King, A.S., Breazile, J.E., Evans, H.E., and Vanden Berge, J.C. (eds.), Handbook of Avian Anatomy: Nomina Anatomica Avium, Second Edition. Publications of the Nuttall Ornithological Club 23, Cambridge.

Boie, F. 1822. Tagebuch gehalten auf einer Reise durch Norwegen im Jahre 1817. Taubstummen Institut, Schleswig.

Brazil, M. 2009. Birds of East Asia. China, Taiwan, Korea, Japan, and Russia. Princeton University Press, Princeton.

Cai, M., Fang, X., Wu, F., Miao, Y., and Appel, E. 2012. Pliocene-Pleistocene stepwise drying of Central Asia: Evidence from paleomagnetism and sporopollen record of the deep borehole SG-3 in the western Qaidam Basin, NE Tibetan Plateau. Global and Planetary Change, 94-95:72-81.

Cai, Q., Qian, X., Lang, Y., Luo, Y., Xu, J., Pan, S., Hui, Y., Gou, C., Cai, Y., Hao, M., Zhao, J., Wang, S., Wang, Z., Zhang, X., He, R., Liu, J., Luo, L., Li, Y., and Wang, J. 2013. Genome sequence of ground tit Pseudopodoces humilis and its adaptation to high altitude. Genome Biology, 14: R29. doi:10.1186/gb2013-14-3-r29. 
Chang, M., Wang, X., Liu, H., Miao, D., Zhao, Q., Wu, G., Liu, J., Li, Q., Sun, Z., and Wang, N. 2008. Extraordinarily thick-boned fish linked to the aridification of the Qaidam Basin (northern Tibetan Plateau). Proceedings of the National Academy of Sciences, 105:13246-13251.

Cheneval, J., Ginsburg, L., Mourer-Chauviré, C., and Ratanasthien, B. 1991. The Miocene avifauna of the Li Mae Long locality, Thailand: systematics and paleoecology. Journal of Southeast Asian Earth Sciences, 6:117-126.

Cheng, T.-H. 1987. A Synopsis of the Avifauna of China. Science Press, Beijing.

Deng, T., Wang, X., Fortelius, M., Li, Q., Wang, Y., Tseng, Z.J., Takeuchi, G.T., Saylor, J.E., Säilä, L.K., and Xie, G. 2011. Out of Tibet: Pliocene woolly rhino suggests high-plateau origin of ice age megaherbivores. Science, 333:1285-1288.

Donne-Goussé, C., Laudet, V., and Hänni, C. 2002. A molecular phylogeny of Anseriformes based on mitochondrial DNA analysis. Molecular Phylogenetics and Evolution, 23:339-356.

Dunning Jr., J.B. 2008. CRC Handbook of Avian Body Masses. Second Edition. CRC Press, Boca Raton, Florida.

Fulton, T.L., Letts, B., and Shapiro, B. 2012. Multiple losses of flight and recent speciation in steamer ducks. Proceedings of the Royal Society $B$, 279:2339-2346.

Hilgen, F.J., Lourens, L.J., Van Dam, J.A., Beu, A.G., Foyes, A.F., Cooper, R.A., Krijgsman, W., Ogg, J.G., Piller, W.E., and Wilson, D.S. 2012. The Neogene Period. pp. 923-978. In Gradstein, F.M., Ogg, J.G., Schmitz, M.D., and Ogg, G.M. (eds.), The Geologic Time Scale 2012, Volume 2. Elsevier, Amsterdam.

Kurochkin, E.N. 1985. Birds of Central Asia in the Pliocene. The joint Soviet-Mongolian Paleontological Expedition, Transactions, 26:1-119.

Lang A., Bishop, M.A., and Le Sueur, A. 2007. An annotated list of birds wintering in the Lhasa river watershed and Yamzho Yumco, Tibet Autonomous Region, China. Forktail, 23:1-11.

Leach, W.E. 1820. Eleventh room. pp. 65-70. In Synopsis of the contents of the British Museum, Seventeenth Edition. British Museum (Natural History), London.

Lei, F., Qu, Y., and Song, G. 2014. Species diversification and phylogeographical patterns of birds in response to the uplift of the Qinghai-Tibet Plateau and Quaternary glaciations. Current Zoology, 60:149-161.

Li, J., Ge, C., Li, Z., Xu, A., and Li, Y. 2010. Summer bird diversity along the Qinghai Section of the QinghaiTibet Railway. Sichuan Journal of Zoology, 29:657664.

Li, J., Fang, X., Song, C., Pan, B., Ma, Y., and Yan, M. 2014. Late Miocene-Quaternary rapid stepwise uplift of the NE Tibetan Plateau and its effects on climatic and environmental changes. Quaternary Research, 81:400-423.
Linnaeus, C. von. 1758. Systema naturae per regna tria naturae, secundum classes, ordines, genera, species, cum characteribus, differentiis, synonymis, locis. Editio decima, reformata. Holmiae, Laurentii Salvii. [1-4].

Livezey, B.C. 1997. A phylogenetic analysis of modern sheldgeese and shelducks (Anatidae, Tadornini). Ibis, 139:51-66.

Luo, Z.-K., Zhang, W.-H., Hou, Y., Li, X.-Y., Liu, W., and Li, Z.-J. 2013. Seasonal dynamics and habitat selection of Ruddy Shelduck (Tadorna ferruginea) (Anseriformes: Anatidae) in alpine wetland ecosystem of Southwest China. Acta Zoologica Bulgarica, 65:469478.

MacKinnon, J. and Phillipps, K. 2000. A Field Guide to the Birds of China. Oxford University Press, Oxford.

Madsen, D.B., Lai, Z., Sun, Y., Rhode, D., Liu, X., and Brantingham, P.J. 2014. Late Quaternary Qaidam lake histories and implications for an MIS 3 "Greatest Lakes" period in northwest China. Journal of Paleolimnology, 51:161-177.

Mayr, G. and Clarke, J. 2003. The deep divergences of neornithine birds: a phylogenetic analysis of morphological characters. Cladistics, 19:527-553.

McCracken, K.G., Barger, C.P., Bulgarella, M., Johnson, K.P., Sonsthagen, S.A., Trucco, J., Valqui, T.H., Wilson, R.E., Winker, K., and Sorenson, M.D. 2009. Parallel evolution in the major haemoglobin genes of eight species of Andean waterfowl. Molecular Ecology, 18:3992-4005.

McCracken, K.G., Barger, C.P., and Sorenson, M.D. 2010. Phylogenetic and structural analysis of the $\mathrm{HbA}(\alpha \mathrm{A} / \beta \mathrm{A})$ and $\mathrm{HbD}(\alpha \mathrm{D} / \beta \mathrm{A})$ hemoglobin genes in two high-altitude waterfowl from the Himalayas and the Andes: Bar-headed goose (Anser indicus) and Andean goose (Chloephaga melanoptera). Molecular Phylogenetics and Evolution, 56:649-658.

Mischke, S., Sun, Z., Herzschuh, U., Qiao, Z., and Sun, N. 2010. An ostracod-inferred large Middle Pleistocene freshwater lake in the presently hyper-arid Qaidam Basin (NW China). Quaternary International, 218:74-85.

Olson, S.L. 1985. The fossil record of birds. pp. 79-252. In Farner, D.S., King, J.R., and Parkes, K.C. (eds.), Avian Biology, Volume 8. Academic Press, New York.

Pillans, B. and Gibbard, P. 2012. The Quaternary Period. pp. 979-1010. In Gradstein, F.M., Ogg, J.G., Schmitz, M.D., and Ogg, G.M. (eds.), The Geologic Time Scale 2012, Volume 2. Elsevier, Amsterdam.

Reichenbach, H.G.L. 1849-1850. Avium Systema Naturale: Vorläufer einer Iconographie der Arten der Vögel aller Weltheile, welche, nachdem bereits fast dreitausend Abbildungen erschienen sind, ununterbrochen fortgesetzt wird. Hofmeister, Leipzig. 
Sun, Z., Li, J., Zhan, S., Wang, P., Wang T., and Li, Y. 1995. Areal distribution of Quaternary ostracod assemblages and its main controlling factor in Chaidamu Basin, NW China. pp. 277-281. In Riha, J. (ed.), Ostracoda and Biostratigraphy. A.A. Balkema, Rotterdam.

Wagler, J.G. 1831. Einige Mittheilungen über Thiere Mexicos. Isis von Oken, 5:510-535.

Wang, X., Li, Q., Qiu, Z., Xie, G., Wang B., Qiu Z., Tseng, Z.J., and Takeuchi, G.T. 2013. Chapter 10. Neogene mammalian biostratigraphy and geochronology of the Tibetan Plateau. pp. 274-292. In Wang, X., Flynn, L.J., and Fortelius M. (eds.), Fossil Mammals of Asia: Neogene Biostratigraphy and Chronology. Columbia University Press, New York.

Wang, X., Qiu, Z., Li, Q., Wang, B., Qiu, Z., Downs, W.R., Xie, G., Xie, J., Deng, T., Takeuchi, G.T., Tseng, Z.J., Chang, M., Liu, J., Wang, Y., Biasatti, D., Sun, Z., Fang, X., and Meng, Q. 2007. Vertebrate Paleontology, biostratigraphy, geochronology, and paleoenvironment of Qaidam Basin in Northern Tibetan Plateau. Palaeogeography, Palaeoclimatology, Palaeoecology, 254:363-385.

Wang, X., Wang, Y., Li, Q., Tseng, Z.J., Takeuchi, G.T., Deng, T., Xie, G., Chang M., and Wang, N. 2014. Cenozoic vertebrate evolution and paleoenvironment in Tibetan Plateau: Progress and prospects. Gondwana Research, DOI:10.1016/j.gr.2014.10.014.

Watanabe, J. and Matsuoka, H. 2013. Ontogenetic change of morphology and surface texture of long bones in the Gray Heron (Ardea cinerea, Ardeidae). pp. 279-306. In Göhlich, U.B. and Kroh, A. (eds.), Paleornithological Research 2013: Proceedings of the 8th International Meeting of the Society of Avian Paleontology and Evolution, Vienna, 2012. Verlag Naturhistorisches Museum, Vienna.

Worthy, T.H. 2009. Descriptions and phylogenetic relationships of two new genera and four new species of Oligo-Miocene waterfowl (Aves: Anatidae) from Australia. Zoological Journal of the Linnean Society, 156:411-454.

Worthy, T.H. and Lee, M.S.Y. 2008. Affinities of Miocene waterfowl (Anatidae: Manuherikia, Dunstanetta, and Miotadorna) from the St Bathans fauna, New Zealand. Palaeontology, 51:677-708.
Worthy, T.H., and Pledge, N.S. 2007. A shelduck (Anatidae: Tadorna) from the Pliocene of South Australia. Transactions of the Royal Society of South Australia, 131:107-115.

Worthy, T.H., Tennyson, A.J.D., Jones, C., McNamara, J.A., and Douglas, B.J. 2007. Miocene waterfowl and other birds from Central Otago, New Zealand. Journal of Systematic Palaeontology, 5:1-39.

Wu, F., Fang, X., Hermann, M., Mosbrugger, V., and Miao, Y. 2011. Extended drought in the interior of Central Asia since the Pliocene reconstructed from sporopollen records. Global and Planetary Change, 76:16-21.

Xing, L., Lockley, M.G., and Falk, A. 2013. First record of Cenozoic footprints from East Asia (Tibet, China). Ichnos, 20:19-23.

Yang, Y., Fang, X., Galy, A., Appel, E., and Li, M. 2013. Quaternary paleolake nutrient evolution and climatic change in the western Qaidam Basin deduced from phosphorus geochemistry record of deep drilling core SG-1. Quaternary International, 313-314:156-167.

Yang, F., Sun, Z.-C., Ma, Z.-Q., and Zhang, Y.-H. 1997. Quaternary ostracode zones and magnetostratigraphic profile in the Qaidam Basin. Acta Micropalaeontologica Sinica, 14:378-390.

Yang, Y., Yi, X., and Li, N. 2009. Analysis on trophic structure of main waterbirds in Qinghai Lake based on stable isotopic technology. Zoological Research, 30:418-422.

Zelenkov, N.V. 2013. Miocene evolution of Eurasian ducks. Casarca, 16:13-36.

Zelenkov, N.V. and Kurochkin, E.N. 2011. The current state of knowledge of Neogene birds of Central Asia. pp. 44-70. In Martynovich, N.V. (ed.), Arkadiyu Yakovlivechu Tugarinovu posvyaschaetsya (Devoted to A.Ya. Tugrinov) a collection of scientific papers. Krasnoyarsk Regional Natural History Museum, Krasnoyarsk.

Zelenkov, N.V. and Martynovich, N.V. 2013. The oldest avian fauna from Baikal. Baikal Zoological Journal, 11:12-17. (In Russian)

Zhuang, G., Brandon, M.T., Pagani, M., and Krishnan, S. 2014. Leaf wax stable isotopes from Northern Tibetan Plateau: Implications for uplift and climate since $15 \mathrm{Ma}$. Earth and Planetary Sciences Letters, 390:186-198. 